\title{
Adult Suppository Dosage Form
}

National Cancer Institute

\section{Source}

National Cancer Institute. Adult Suppository Dosage Form. NCI Thesaurus. Code C64886.

A suppository intended for administration to adults. 